\title{
The Making of World Literature: Slavno je za otadžbinu mreti by Danilo Kiš and Mily dicső a hazáért halni by Péter Esterházy
}

\section{Abstract}

The paper develops in a specific reading strategy of appropriation of Danilo Kiš's story Slavno je za otadžbinu mreti in Péter Esterházy’s literary opus (first in the story Mily dicső a hazáért halni, published in Hungarian in 1986 with changes due to aspects of the text that are necessarily changed in translation, then in his Introduction to Literature and Celestial Harmonies), in order to offer possible answers to the following questions: What is the role of (in-)translation in the study of literature? What does the metaphor of elliptical refraction (Damrosch) mean as "the most convenient" description for world literature? If the stories of Kiš and Esterházy are the same, but written in different languages and received in different cultural, historical, and social contexts, can we refer to it as one literary work? If the author is different - is the literary work only seemingly the same? Who, in fact, is the author - if Esterházy read and used Kiš's story in translation? How does this vortex-like example contribute to our understanding of world literature, its problems and difficulties, neuralgic and "blind" spots? Who authors world literature canon? How do notions of origins and authenticity resonate in the field of world literature?

Keywords: world literature, Danilo Kiš, The Encyclopedia of the Dead, Péter Esterházy, Harmonia Cælestis, Central-European literary space, elliptical refraction, "in-translation," stereotext, Mikhail Epstein 
"I think of literature as my country of origin. I am for Goethe's concept of world literature." (Kiš, The Conscience of an Unknown Europe)

"Migration is cultural mutation, it is the change of hereditary characteristics that results from the reconstructions and destructions in the informational code of both cultures' senders and receivers. Mutations in nature and migrations in culture are decisive factors in evolution. They lead to the emergence of new species and are the foundation of the mutability in developing systems of life and consciousness." (Epstein, Amerussia: Biculturalism and Liberty)

In his comprehensive analysis of the ways in which works of world literature can best be read, David Damrosch poses the question of whether something that is not world literature can exist, somewhat cynically concluding that a "category from which nothing can be excluded is essentially useless" (Damrosch 110). In an ironical twist, his own book, entitled What Is World Literature?, concludes with a fairly decisive, threefold definition of what world literature actually is, proving that, firstly, although the category may seem useless (the concept of "world literature" as a "floating signifier"), there obviously is such a thing as world literature, and, secondly, that it does make sense to engage in such scholarship. Departing from the premise that world literature is rather a complex strategy of reading, an experience of migration, than a fixed canon of texts, the paper analyzes the phenomenon of "in-translation" (Casanova 2007) as one of the central ways by which world literature canon is articulated, negotiated and maintained. A comparison of the short story Slavno je za otadžbinu mreti by Danilo Kiš with Péter Esterházy’s Mily dicső a hazáért halni, published in Hungarian in 1986 with changes due to aspects of the text that are necessarily changed in translation, a text that was a cornerstone for his world famous works, such as Introduction to Literature and Celestial Harmonies, offers particularly valuable insights into how literature operates: through a complex set of gestures, such as the establishment of hierarchy and translation as determining mode of re-writing, re-interpretation and, finally, co-optation in the national literature canon, however defined. The example of Kiš's (and/or Esterházy's) story is especially symptomatic when we take into consideration that the beginning of Kiš's story reverts to Horatius' Dulce et decorum est pro patria mori (Odes 3.2), which is one of the best known yet also notoriously puzzling lines in the canon of classic literature. 


\section{1}

In her essay "Answering for Central and Eastern Europe," Caryl Emerson claims that the CentralEuropean region is "intuitively "comparative"” (Emerson 203). Not only that "one town would commonly speak several native languages, belong to two or three empires in the course of a single generation" (203), but most of its residents are also "hybrids who carried the dividing-lines of nationality within themselves" (203). Vladimir Biti rightly continues to develop a similar argument by claiming that this region is "comparative by birth" (Biti 2). Moreover, another point made by Caryl Emerson is worth mentioning: "Exile, displacement, multilanguagedness, heteroglossia, outsideness to oneself and thus a taste for irony, the constant crossing of borders, and the absence of a tranquil, organic, homogenized center that belongs to you alone: all these Bakhtinian virtues and prerequisites for genuine dialogue have long been endemic to Central Europe" (Emerson 203-04) $!^{[1]}$ All these areas are a fruitful starting point for this analysis, in which I would like to address something that is a good pool for interpretation of various issues associated with world literature: what it is, i.e. what do we talk about when we talk about world literature, and how we can define a world literary work. In addition to this, I am interested in the place Central European literary practices occupy. The example of the seemingly one-sided inscription of Danilo Kiš’s story "Pro Patria Mori” (“Slavno je za otadžbinu mreti” - literally, "To Die for One's Country is Glorious") in Péter Esterházy's earlier writings, and in his seminal work, Celestial Harmonies ( Harmonia Cælestis, 2001), is at the same time a striking and uncommon example of this "intuitive comparativeness." This paper aims to accentuate the aesthetic logic which underlies Esterházy's non-normative crossing of borders in this particular transfer of Kiš's story because it tells us something considerably crucial for understanding the world literature as terminus technicus. I will start with several general observations and move on with the analysis of how literary scholarship on world literature can benefit from moving away from the already well-established, but somewhat reductionist, story about plagiarism in relation to Esterházy's uses of Kiš’s story "Pro Patria Mori."

At least three different understandings of world literature are in circulation today: 1) "exotic literature, verbal art of the world beyond their own," 2) "universal cannon of masterpieces: the proverbial best that has been thought and said across histories and cultures," 3) "innumerable 
works that travel globally, exposing themselves to readers in new places and languages and taking part in the flows of transcultural interaction and exchange" (Etherington and Zimbler 1). Another important issue, which is one of the most widely used conceptions of "world literature" in literary scholarship nowadays, is that world literature implies a certain understanding of the world as a planet or globe (2) - but we all know that the world is "both more and less than this" (2). The term "world"

originates from a sense both of the particularity of humanity's experience, and of the here and now, rather than the far and distant. It is one of a number of cognates belonging to Germanic languages

- Welt (German), wereld (Dutch), värld (Swedish), verden (Danish) - that trace their roots to a nominal compound meaning something like 'age of man.' Their meanings thus come to include: the material world; humanity's present; temporal state of existence; earthly things, or temporal possessions; an age; a person's conditions of life; the course of human affairs." (2-3)

To that end, world literature is "both more and less" than what we often mechanically take for granted, and therefore I want to put forth the idea of world literature as a totality according to which a world literary work "somehow encodes the logic of world literary totality" (Etherington 54). In order to talk about world literature, we in fact need to talk about literary totality. So, what does this mean?

If we claim that "the history of world literature is the history of notions of literary totality" ( Chronology xiii), then "a simple list of significant literary works and their dates of publication would not be a chronology of world literature but a version of world literary history produced in accordance with one such notion" (xiii). So, when we talk about the notion of literary totality, we talk about a "broader set of reflections and methodological possibilities" (Etherington and Zimbler 4), which is historically and culturally conditioned, wherein totality implies those "which is concerned with total" (4). Just for illustration, the timeline of conceptions of literary totality may include such works as Aristotle's Poetics in 335 BCE, Dante's De vulgari eloquentia (1302-1305), Sidney's An Apology for Poetry (1595), Herder's Briefe zur Beförderung der Humanität (1793), Veselovsky's “Try glavy iz istoricheskoj poetiki” (1899), Croce's Estetica come scienza dell' espressione e linguistica generale (1902), Lukács's Die Theorie des Romans (1916), Benjamin's Das Kunstwerk im Zeitalter seiner technischen Reproduzierbarkeit (1936), Propp's Morfologia skazki (1928), 
Bakhtin's Problemy tvorchestva Dostoevskogo (1929), Roman Jakobson's "Closing Statement: Linguistic and Poetics" (1958) or Paul Celan's "Der Meridian" (1961), and end with Amir Mufti's book Forget English!, published in 2016 (Chronology). Despite few omissions, the editors of The Cambridge Companion to World Literature made an insightful but also a strategically important methodological breakthrough for any further analysis of world literature: the book doesn't offer just a list of world literature works. Rather, it gives an overview of the ideas of totality and the historical relations between the ideas of literary totality and actual literary practices.

To that end, I would set two starting points for this analysis. Firstly, "world literature, as an object of study, has to be made; it cannot simply be found" (Andrews 227). World literature is made possible by various things: the development of the literary field in general - first and foremost, in the process of creating literary works, but also by a parallel development of literary infrastructure, which includes critical literary theory. Secondly, "world literature will be deemed a necessary concept or category only if it proves vital to understanding actual literary practices" (Etherington and Zimbler 6).

\section{2}

Danilo Kiš was a Yugoslav writer, most notable for his masterpieces such as A Tomb for Boris Davidovich (Grobnica za Borisa Davidoviča, 1976), The Anatomy Lesson (Čas anatomije, 1978) and The Encyclopedia of the Dead (Enciklopedija mrtvih, 1983). He lived in Paris for the last several years of his life. One of the reasons for this was the accusation of plagiarism, which followed the publication of A Tomb for Boris Davidovich. Kiš's The Anatomy Lesson is a response to what the scholarship of the time called the biggest literary scandal and controversy in pre-war Yugoslavia. The short story "Slavno je za otadžbinu mreti" ("Pro Patria Mori”), whose title evokes Horatius' "Dulce et decorum est pro patria mori" (Odes 3.2), was published in Kiš's masterpiece The Encyclopedia of the Dead in 1983. The main character of the story is "young Esterházy," whose execution for political rebellion was ordered by an Imperial decree. Court has treated "His descent and the renown of his family ... as a betrayal not only of the monarch but also of his own class" (Kiš, Encyclopedia 103), so the punishment "was meant to set an example" (103). Young Esterházy is not so afraid of dying - instead, he fears not being able "to preserve the dignity 
required of an Esterházy at such a moment" (103). His courage is interrupted by a visit from his mother: "She had stood before him, solid, strong, with a veil over her face, filling the cell with her personality, her persona, her character, her large plumed hat and her skirts" (105). She tells him she will throw herself at the feet of the one who has the life of her son in his hands, and if she succeeds in saving his life, the next morning, she will be standing in white. The next day, his mother is standing all in white; nevertheless, he is executed. Still, since his own mother tricked him by wearing a white dress, the one he knew well because one of his ancestors had worn it to an Imperial wedding (107), he - until the very end - does not believe he will "be hanged like some highwayman" (107). His courage and calmness in the moment of his death turned into a legend (107) - one version of this legend is offered to us by Kiš's story. Croatian scholar Tatjana Jukić already mentioned a special configuration of the female figure in this novel: the story is "dominated by a cold, Oedipus mother who believes that the honorable death of her son is more important than the truth" (Jukić, "Plus d'un" 102). The novel ends with the following, rather clichéd phrases: "History is written by the victors. Traditions are woven by the people. Writers fantasize. Only death is certain" (Kiš, Encyclopedia 106).

It is important to emphasize that this story is part of the collection The Encyclopedia of the Dead, which was created, as Kiš wrote in Postscript, in the spirit of an obsessive theme in world literature: "ever since the Gilgamesh epic, death has been one of the obsessive themes of literature" (159). The book's epigraph, Georges Bataille's famous words "Ma rage d'aimer donne sur la mort comme une fenêtre sur la court" (literally, "The rage of my love looks at death as a window looks at a courtyard"), allows us to read the whole collection of stories from the perspective of the theme of death, to that extent death is manifested in the forms of eros and thanatos. At the level of content, the story can be seen as a literary work which is concerned with the total - not only the very theme of violence or violent death, especially in relation to eros as another fundamental drive, but also as that of the mother-son plot, particularly an Oedipus mother, reverberating through the literary field from its beginnings. With its very form, Kiš's masterpiece gives an interesting reflection of the idea of literary totality, as the encyclopedia is a Borgesian 'emporium of knowledge', a book of absolute knowledge. ${ }^{[2]}$ 
The Encyclopedia of the Dead was translated into Hungarian in 1986, and the same year, the Hungarian translation of Kiš's story appeared in two of Esterházy's works ${ }^{[3]}$ The version in the literary journal Életünk (5/1986) was translated by Endre B. Bojtár, who was then a student of Yugoslav studies in Budapest. The title credits Kiš, and the story ends with the same words as Kiš's original text:

\section{ESTERHÁZY PÉTER}

"Danilo Kiš: Mily dicső a hazáért halni«

\section{- BEVEZETÉS A SZÉPIRODALOMBA -}

(Bojtár B. Endre forditása:) Amikor azon az áprilisi hajnalon, mely a császári dekrétum értelmében kivégzésének hajnala volt, az örök a cellába léptek, az ifjú Esterházy a földön térdelt, s kezeit szorosan összekulcsolva imádkozott... . (Esterházy, "Danilo Kiš" 385)

Other more formal characteristics of Kiš's text have been kept.

The story was republished in Esterházy’s An Introduction to Literature (Bevezetés a szépirodalomba) in 1986, after Kiš’s The Encyclopedia of the Dead was already published in Hungarian ("Forum," Novi Sad, and translated by Sándor Borbély). Nothing has been changed at the level of form or meaning, but one significant change did occur. Kiš's and translator's names disappeared from the title, and a reference to Kiš has been added in the form of a graphically distinguished sentence at the end of the story.

A történelmet a győztesek írják. A legendákat a nép szövi. Az írástudók fantáziálnak. Bizonyos csak a halál. ${ }^{[4]}$

A fenti szövegben, többek közt, szó szerinti vagy torzított formában Danilo Kiš-idézetek vannak. (Esterházy, "Danilo Kiš" 645) ${ }^{5]}$

For Esterházy, literature "is a dialogue between good books" (Sollosy $\mathrm{x}$ ). His poetics is based on the abundant use of intertextuality, on the "ubiquitous use of quotation" (Aczel vii), and on releasing 
multiply articulated textual spaces. For this reason, it is worth recalling Esterházy's explanation of why he borrowed Kiš's story. After reading it, he concluded:

His literary process was very similar, almost identical to mine. And then, it was a marvellous experience when I read the short story 'Pro Patria Mori.' When I read it, I felt as if that was my text.

A text I could never write myself, but a text that somehow belonged to me. It is a short story in which the main character is a certain Esterházy. The appearance of this word sends the text down a very unusual path. I venture to say that the 900 pages of my novel 'Celestial Harmonies' in a way came out of that short story. (qtd. in Dugandžija)

This final remark by Esterházy is especially intriguing for at least two reasons. Firstly, while Kiš conceived the work as universal (the encyclopedia as a book of absolute and universal knowledge of death in its manifestation through eros and thanatos), Esterházy read Kiš's story first and foremost as an account of the tragic destiny of his own family, told through a surname, which, as we know, was simultaneously mythical and traumatic for the writer. In this, he also saw a very specific Central European way of translating the past. If we take into consideration that this story is just one among others in the Encyclopedia, in a way, Esterházy "localized" the horizon of Kiš's universal idea. He narrowed and aligned Kiš's story more clearly with the tradition of Central European cultural space, however defined. In other words, Esterházy stripped Kiš's story of the literary totality, which was constitutive of it. On the other hand, this transfer can be observed as a mutual gift (Marcel Mauss writes that "the obligation attached to a gift itself is not inert. Even when abandoned by the giver, it still forms a part of him" [9]). We could read Esterházy's gesture as an expression of his support, because at the time Kiš was accused of non-originality in his works. Yet, of course, there is more to it, because in a way, and without knowing it, Esterházy fulfilled the task Kiš assigned to another imagined, future author. To quote Kiš's own words from the interview Seeking a Place under the Sun for Doubt (Tražim mesto pod suncem za sumnju):

When I describe The Encyclopedia of the Dead as a meeting place for all human events, I mean it as a metaphor for my own poetics in an ideal, unattainable form. It's a description of an ideal project of condensation, the final product of which is the story The Encyclopedia of the Dead, which in fact is a condensed novel, a novel reduced to some forty pages. I might add that another writer, less indolent and with a different poetics, would doubtless have turned the same material 
into a full-fledged classical, nineteenth-century-like psychological novel, something a lot fatter than, say Maupassant's Une vie. (201)

When he talks about The Encyclopedia of the Dead here, Kiš, of course, is not referring to the whole book, but only to the story that shares the book's name. Therefore, Esterházy, by writing "a full-fledged novel," Celestial Harmonies, does what Kiš did not, and probably could not, do. On the other hand, in the framework of Bakhtinian dialogism, we must ask the question: Can an idea be adequately presented in only one language? Or, if there is no being but only co-being (Russ. sobytie), i.e. "co-being of being" (Russ. sobytie bytiya) ${ }^{[6]}$, if "my self needs the other, to become an I-for-the-other" (Morris 246), perhaps a literary work needs a minimum of two languages to release at least some of its meanings? ?] $^{7]}$ That becomes especially relevant if we take into account that according to the Postscript at the end of Encyclopedia - Kiš clearly stated that, in fact, he was the one who borrowed the legend about Esterházy. The story "is a free reworking of a Late Bourgeois legend, which was by that time the subject of a number of variations, all of them based on Austrian sources not devoid of partiality and sentimentality" (164). Taking everything mentioned into account, it becomes clear that it is impossible to decisively distinguish who is the giver of a gift and who the receiver, which is inscribed especially visibly in the third, most intriguing and the last use of Kiš's story by Esterházy. Kiš's story is the 24th Sentence in Esterházy's seminal work Harmonia Cælestis. In relation to Kiš's original text, we can find several significant changes.

First, there is the adoption of Kiš's character. In Celestial Harmonies, Kiš's "officer Esterházy" becomes "my dear father," Esterházy’s mother becomes "my grandmother" (so it is not a surprise that the audience accepted this story as his autobiography). The second, and perhaps even more important change, is that in Esterházy's version of Kiš's text there is no dynamic exchange of direct and indirect speech, which was constitutive of Kiš's story - all the characters of the story seemingly speak for themselves, creating the illusion of authenticity and multivoicedness. That being said, the first part of Celestial Harmonies relies on multiplication of different versions of a legend, and the abundant use of the phrase "and here my father's name followed" (“az ifjú, itt édesapám neve következett") everywhere where one could, would or should expect the family surname: 
... És valami furcsa, fölcserélt időrendben MÁR MOST hallotta, amint az őr a tiszti kaszinóban meséli: Uraim, az ifjú, itt édesapám neve következett, az éjjel mély álomba merülve aludt. Egy sóhaj nélkül. Mintha esküvő és nem kivégzés várna rá. Tiszti becsületszavamra mondom! Uraim, adózzunk neki elismeréssel. És hallani (hallja) a kristálypoharak csörrenését is. Prosit! Prosit! ... (Esterházy, Harmonia cælestis 26) ${ }^{[8]}$

... I on je, u nekom čudnom redosledu vremena, već čuo kako taj stražar priča u oficirskoj kasini: “Gospodo, mladi je Esterhazi te noći spavao mrtvim snom, bez uzdaha, kao pred venčanje a ne pred pogubljenje. Dajem vam svoju časnu oficirsku reč! Gospodo, odajmo mu priznanje!" Onda se čuje (on čuje) kristalni zvuk čaša. „Eks! - Eks!“ ... (Kiš, Enciklopedija mrtvih 1499)

Celestial Harmonies is narratively structured around numerous replications and iterations of possible versions of "my father's" life - on the basis of different sentences that came from different places, that are "always intertextual" (Esterházy 843) - from sentences the author overheard on the street and sentences of Barthelme, Beckett, Bellow, Daly, Ginzburg, Gombrowicz, Jerofeyev, Joyce, Kolakowski, McCourt, Nabokov, Roth, Updike (843-844), to, finally, one version of "young Esterházy's life" in Kiš’s own re-writing of a legend. ${ }^{[0]}$

What is the meaning of this loss of direct/indirect speech on the one hand, and of the abundant use of a phrase "and here my father's name followed," on the other, in different words, the skillful intertwinement of diegetic levels which creates a sense of doublevoicedness? This point takes me back to the matter of how our knowledge of world literature as a term can benefit from such an analysis because this part (or these parts) offer(s) an answer to probably two key challenges of contemporary literary scholarship worldwide. (And this is where the necessity to place the issue of literary totality in the middle of our discussions of world literature comes to the forefront.) Here, I am talking about the issue of the text (that "dangerously unfocused term," as noted by Clifford Geertz in his book Local knowledge 30), and, along with it, the issue of authorship.

The author is, and I am here quoting Ernő Kulcsár Szabó's reading of Géza Szőcs's uses of Shakespeare, "a 'transferring point' of activities in order for them to be disseminated once again" (77). On the other hand, in order to be disseminated again in a "defamiliarized" (Russ. ostranenie) 
form of repetitions of "my father's" story / stories, this sentence states that Esterházy's subject, as Kulcsár Szabó also noted in his analysis of his work, reflects upon this general intertextual situatedness like a crossroads of systemic conflicts (77). The argument can be pushed forward along the line of the analysis of the "overburdened historical meaning of 'Esterházy,"' as Sándor Hites wrote in his paper The Hungarian Historical Novel in Regional Context: "The ceaseless displacements, the transformations that subvert the identity of the central trope, the father, make a linear following of the genealogy impossible" (478). In the light of this paper's reading of Esterházy's novel, through the eyes of Kiš's story, I would emphasize that the word "genealogy" is not only related to the genealogy of Esterházy's family, metonymically expressed by this at once universal, omnipresent and absent father, but also to the genealogy of Kiš's story in particular, and - more broadly - to the principles of his poetics in general. I would agree with Hites's reading of Esterházy's novel, according to which narrative gesture of constant play, of delicate oscillation between fact and fiction creates "several centres of meaning by constantly recomposing the historical context" (478) instead of erasing them. To that end, it would be important to emphasize that, if it would be possible to explain the main principles of Kiš's poetics in general in a single sentence, then the quoted sentence from Hites's reading of Esterházy's Celestial Harmonies would be the one. So, Esterházy's use of Kiš's significantly contributes to our understanding of Kiš's homo poeticus.

However, one question needs to be asked: are we really talking about intertextuality when an absolute shift in modality occurs, when someone else's text is appropriated with the aim of writing a family portrait (which is for Esterházy at the same time a portrait of his image of Hungary), or, to be more precise, of creating different versions of possible autobiographies?

In fact, I believe we're not even speaking about dialogism or intertextuality, and more about interlation, about stereotextuality, which the Russian philosopher Mikhail Epstein, in his essay coincidently written the same year as Celestial Harmonies, sees as "the future of human communication." According to Epstein, stereotextuality is "when languages will not be expected to replace but to supplement each other.... This super-posing of texts of different languages, this stereotext will produce a more striking, stratified, and deeper image of a single complex of ideas" (“Amerussia: Biculturalism and Liberty”). Celestial Harmonies, with the repetitiveness of possible 
versions of "my father's story, ${ }^{\lceil 11]}$ is an illustrative enough example of those text(s) with rich and loud "stereo effect" (at the end of this paper I will offer another striking example of this effect in contemporary Croatian culture).

\section{3}

This example shows that the structure of both Hungarian and Serbian (or Croatian or Yugoslav, or East-Central European, or Austro-Hungarian for that matter) literary field, in Bourdieaun terms, is necessarily modified by Esterházy's uses of Kiš's story outside of its initial context, and that various conflicts have arisen around the forms of these arrivals and diffusions. Bourdieau's field-based model suggests that the understanding of a literary work as a network of activities simultaneously calls for an analysis of the "literary craft as relational practice" (Zimbler 71). Naturally, this relationality doesn't refer only to how literature operates in relation to other forms of artistic expressions and knowledge in a cultural field, but also within its very being (within each seemingly autonomous literary work). A close reading of the metaleptic shifts of Kiš's text in Esterházy's literary works illuminates the acute awareness of both authors that a particular text originates in various discourse constellations - from the conditions of its origin to its copy, cultural transfer, and, finally, reception.

At the same time, this analysis accentuates something we often take for granted - translation is a key component to the circuits of world literature (Helgesson 86). I am not suggesting here that translation itself was not important - after all, Esterházy got acquainted with Kiš's story in translation. Still, I would like to emphasize that when we talk about translation in the context of the understanding of world literature as, according to Damrosch, group of texts which circulate beyond their culture of origin (Damrosch; Bernard 40), this particular example shows how these things are much more complicated than that. Epstein's concept of stereotext "counts on the difference, on immanent non-equivalence of languages and creates a non-linear, multi-dimensional image of the subject by combining linguistic projections" (Ot znanija 319) $!^{[12]}$ The logic, which underlies Epstein's claims, is that languages have their own particular possibilities of expressivity, and boundaries between them are not always crossable! ${ }^{[13]}$ To that end, "If the translation annihilates the effect of difference, ... the stereotext rather suggests interlation of languages (Russ. svod 
jazykov) in a three-dimensional perspective" (Epstein, "Stereotekst" 229) ${ }^{[14]}$ Caryl Emerson's insightful comment is more than applicable in this case, and it relates to the issue of translation (often understood too mechanically, too literally in writings about world literature) as a crucial component for breaking all boundaries and allowing the circuits of world literature: when she discussed comparative literature in the age of multiculturalism, she remarked that "What had broken the visibility barrier was not the languages themselves and ... not their classic literary texts, but an arsenal of devices, methods, and rationales (such as 'literariness') for linking all literary products at some higher level" (Emerson 207).

What I tried to show in this analysis was that the private interest of Esterházy for Kiš's story not only re-designated a certain cultural space of Central Europe through Esterházy's appropriation of Kiš's story but his interest offered a model of understanding world literature. So, at the end of this analysis, I will go back to its beginning, i.e. to the methodological reframing of world literature as a technical term for the idea of literary totality as a changeable but defining category of world literature as a complex set/circuit of practices. Since more than one current, prominent notion regarding literary totalities is made visible by Esterházy's uses of Kiš's text, and I assume that stereotextuality would be the less obvious one among them. (There are, roughly speaking, two of the most influential understandings of text in contemporary scholarship: one is Lotman's, with his idea of a text as a box; another one is Derridian, with his idea of a text as entity with no borders where "no meaning can be determined out of context, but no context permits saturation" [Derrida 81]) The latter is mostly applied in the analysis of both Kiš's and Esterházy's writings, and I am not suggesting that we should stop thinking about their forms of textuality in that manner. Yet, this example (or these examples) demand(s) a shift in our way of thinking about the text because we here indeed talk about something else, about a certain stereotext, where notions of frame, structure, and unity not only work together in a completely new way but create "stereo effect" in both cultural fields - sending and receiving, blurring lines between the two, showing that such clear cut division is not possible.

Moreover, "stereo effect" might take different and unpredictable forms, thus proving that Damrosch's concept of "elliptical refraction" of national literatures as one of the most convenient for describing world literature as, indeed, "double in nature" (Damrosch 283). For example, in 2002, an 
anthology of Hungarian short stories was published in Zagreb (Lukač et al.), including two stories by Esterházy, one of them being discussed here. The editors had commissioned a translation of Esterházy's story, seemingly unaware of the fact that the story was by Kiš. Therefore, they had the Hungarian translation of Kiš's story, originally written in Serbian, translated into Croatian. This was reported in the media, as the Serbian Hungarologist Sava Babić, in his defence of Kiš's literary works, attacked the Croatian literary public for forgetting Kiš and condemned the "Croatizing" of Kiš's story originally written in Serbian. One of the editors, Neven Ušumović, told me personally that they had been aware it was actually a story by Kiš, but that they nevertheless decided to commission the translation of Esterházy's Kiš because that further expanded the conceptual and postmodernist connotations of Esterházy's act. Namely, in the new post-war situation ${ }^{[15]}$ in which the question of dividing languages with a clear distinguishing line (what was once Serbo-Croatian and Croatian-Serbian had to became pure Serbian or pure Croatian) became a matter of first-hand political urgency, to commission a Croatian translation marked the continuation of the "game" and a new exploration of the relationship between the "copy" and the "original."

In 2004, the translation of Celestial Harmonies was published in Croatia. The 24th sentence offered a completely new translation. The consequence was the multiplication of Kiš's text in Croatian, thanks to Esterházy - Esterházy's uses of Kiš's text resulted in different Hungarian versions under Esterházy's name, along with numerous versions of "my father's stories" especially in the first, "hard core" (Sollosy viii) part of Harmonia Cælestis, but also in two different Croatian translations of Esterházy's versions of Kiš's text. Since Kiš's story (itself, let us remember, being a version of a legend from an unnamed Austrian source) is getting multiplied every time Esterházy's Celestial Harmonies is translated in world languages, this analysis shows that world literature is indeed about transmission of literary works when they are

being received into the space of a foreign culture, a space defined in many ways by the host culture's national tradition and the present needs of its own writers. Even a single work of world literature is the locus of negotiation between two cultures.... World literature is thus always as much about the host culture's values and needs as it is about a work's source culture; hence it is a double refraction, one that can be described through the figure of the ellipse, with the source and host cultures providing the two foci that generate the elliptical space within which a work lives as 
world literature, connected to both cultures, circumscribed by neither alone. (Damrosch 283; emphasis added)

\section{Works Cited}

Aczel, Richard. Introduction. Helping Verbs of the Heart, by Péter Esterházy, translated by Michael Henry Heim, Quartet Books, 1992, pp. v-ix.

Andrews, Chris. "Publishing, Translating, Worldmaking." The Cambridge Companion to World Literature, edited by Ben Etherington and Jarad Zimbler, Cambridge University Press, 2018, pp. $227-40$

Bernard, Anna. "Nation, Transnationalism, and Internationalism." The Cambridge Companion to World Literature, edited by Ben Etherington and Jarad Zimbler, Cambridge University Press, 2018, pp. 37-51.

Birnbaum, Marianna D. "History and Human Relationships in the Fiction of Danilo Kiš." Cross Currents, vol. 8, 1989, pp. 345-60.

Biti, Vladimir. Introduction: Reexamining the National-Philological Legacy: Quest for a New Paradigm? Reexamining the National-Philological Legacy: Quest for a New Paradigm?, edited by Biti, Rodopi, 2014, pp. 1-21.

Brodsky, Joseph. "The Condition We Call Exile." On Grief and Reason: Essays, by Brodsky, Straus and Giroux, 1995, pp. 22-35.

Casanova, Pascale. The World Republic of Letters. Translated by Malcolm DeBevoise, Harvard University Press, 2007.

"Chronology." The Cambridge Companion to World Literature, edited by Ben Etherington and Jarad Zimbler, Cambridge University Press, 2018, pp. xiii-xx.

Damrosch, David. What Is World Literature? Princeton University Press, 2003.

Derrida, Jacques. "Living On." Translated by James Hulbert. Deconstruction and Criticism, edited by Harold Bloom et al., The Seasbury Press, 1979, pp. 75-176. 
Debeljak, Aleš. "Durable Fiction: Danilo Kiš and His Library." IWM Post, no. 112, 2013/2014, pp. $21-22$

Dugandžija, Mirjana. "Peter Esterhazy - mađarski grof i europska književna zvijezda." Nacional, 25 Feb. 2002, arhiva.nacional.hr/clanak/13384/peter-esterhazy-madarski-grof-i-europska-knjizevnazvijezda. Accessed 4 July 2019.

Emerson, Caryl. "Answering for Central and Eastern Europe." Comparative Literature in an Age of Globalization, edited by Haun Saussy, The Johns Hopkins University Press, 2006, pp. 203-11.

Epstein, Mikhail. "Amerussia: Biculturalism and Liberty; Acceptance Speech for the "Liberty" Prize." Translated by Thomas Epstein. 2000, old.russ.ru/antolog/intelnet/ar_amerussian.html. Accessed 4 July 2019.

Epstein, Mikhail. "Stereotekst." Proektivnyj filosofskij slovar', edited by T. V. Artem'eva et al., vol. 4, Sankt-Peterburg, 2002.

Epstein, Mikhail. Ot znanija - k tvorchestvu. Kak gumanitarnye nauki mogut izmenjat' mir. Tsentr gumanitarnykh initsiativ, 2016.

Esterházy, Péter. "Danilo Kiš: Mily dicső a hazáért halni - Bevezetés a szépirodalomba -." Életünk, vol. 5, 1986, pp. 385-87.

Esterházy, Péter. Bevezet és a szépirodalomba. Magvető kiadó, 1986.

Esterházy, Péter. Harmonia cælestis. Magvető, 2001.

Esterházy, Péter. Celestial Harmonies. Translated by Judith Sollosy, Harper Perennial, 2005.

Etherington, Ben. "Scales, Systems, and Meridians." The Cambridge Companion to World Literature, edited by Etherington and Zimbler, Cambridge University Press, 2018, pp. 52-68.

Etherington, Ben, and Jarad Zimbler. Introduction. The Cambridge Companion to World Literature, edited by Etherington and Zimbler, Cambridge University Press, 2018, pp. 1-19.

Geertz, Clifford. Local Knowledge: Further Essays in Interpretative Anthropology. Basic Books, 1983. 
Helgesson, Stefan. "Translation and the Circuits of World Literature." The Cambridge Companion to World Literature, edited by Ben Etherington and Jarad Zimbler, Cambridge University Press, 2018, pp. 85-99.

Hites, Sandor. "The Hungarian Historical Novel in Regional Context." History of the Literary Cultures of East-central Europe: Junctures and Disjunctures in the 19th and 20th Centuries, edited by Marcel Cornis-Pope and John Neubauer, vol 1., John Benjamins Publishing Company, 2004, pp. 467-79.

Jukić, Tatjana. "Plus d’un: narativni kolektivi Danila Kiša." Sarajevske sveske, no. 37/38, 2012, pp. 93-106.

Jukić, Tatjana. "Between Auschwitz and Siberia: James Joyce, Danilo Kiš, and a Zoning of Totalitarianism." Ireland, West to East. Irish Cultural Connections with Central and Eastern Europe, edited by Aidan O'Malley and Eve Patten Patten, Peter Lang, 2013, pp. 135-58.

Kiš, Danilo. "Banality, Like a Plastic Bottle, is Forever." 1976. Homo Poeticus: Essays and Interviews, edited by Susan Sontag, Farrar, Straus, Giroux, 1995, pp. 165-81.

Kiš, Danilo. "Seeking a Place under the Sun for Doubt." 1984. Homo Poeticus: Essays and Interviews, edited by Susan Sontag, Farrar, Straus, Giroux, 1995, pp. 182-203.

Kiš, Danilo. "The Conscience of an Unknown Europe." 1986. Homo Poeticus: Essays and Interviews, edited by Susan Sontag, Farrar, Straus, Giroux, 1995, pp. 212-30.

Kiš, Danilo. “Jedini jugoslovenski svetski pisac.” 1989. Gorki talog iskustva. 2nd ed., by Danilo Kiš, prepared by Mirjana Miočinović, Beogradski izdavačko-grafički zavod, 1991, pp. 259-65.

Kiš, Danilo. Homo poeticus. Svjetlost, 1990.

Kiš, Danilo. Enciklopedija mrtvih. 3rd ed., Beogradski izdavačko-grafički zavod, 2002.

Kiš, Danilo. The Encyclopedia of the Dead. Translated by Michael Henry Heim, revised and with an introduction by Mark Thompson. Penguin Classics, 2015.

Kulcsár Szabó, Ernő. "Preisgabe der Symmetrie. Zur Eigenart der Postmodernen Intertextualität." Neohelicon, Vol. 20, no. 1, 1993, pp. 65-78. 
Lukač, Stjepan, et al., editors. Zastrašivanje strašila. Antologija mađarske kratke priče. Naklada MD, 2001.

Mauss, Marcel. The Gift. Forms and Functions of Exchange in Archaic Societies. Translated by I. Cunninson, Cohen \& West LTD, 1966.

Morris, Pam, editor. The Bakhtin Reader. Selected Writings of Bakhtin, Medvedev and Voloshinov. Arnold Publishers, 2003.

Sollosy, Judith. A Brief Introduction. 2003. Celestial Harmonies, by Péter Esterházy, translated by Judith Sollosy, Harper Perennial, 2005, pp. vii-xiii.

Varga Oswald, Tina. Péter Esterházy. Uvod u postmodernizam. Ljevak, 2016.

Thompson, Mark. Birth Certificate: The Story of Danilo Kiš. Cornell University Press, 2013.

Zimbler, Jarad. "Literary Worlds and Literary Fields." The Cambridge Companion to World Literature, edited by Ben Etherington and Jarad Zimbler, Cambridge University Press, 2018, pp. 69-84. 
[1] In his essay The Condition We Call Exile, or Acorns Aweigh, written for the Wheatland Conference in Vienna in November 1987, losif Brodsky stated that writers are often in a condition "at which all one is left with is oneself and one's language, with nobody or nothing in between" because "your capsule is your language" (Brodsky 32), writing that "Displacement and misplacement are this century's commonplace" (23). Brodsky's illuminative observations could be taken into account in relation to specificities of literary craft in general: if we consider exile as "a metaphysical condition" (25), every writer, in a sense, is an exilic writer - his/her homeland and at the same time his/her point of departure is his/her (never reachable, never expressible) language. At the same time, even when (s)he is freed (in the language, in his/her literary craft), (s)he is never free (of that same language).

[2] Danilo Kiš was, of course, aware that there cannot be such thing as absolute knowledge - in his interview "Banality, Like a Plastic Bottle, is Forever" ("Banalnost je neuništiva kao plastična boca") writes: "My ideas are woven of skepticism; they are skepticism itself. Their underlying principle might be expressed as follows: don't believe anything anybody says; everyone is a world unto himself, a lone planet, a star - no, stardust - the grain of a meteor meeting other grains by the blind laws of attraction and repulsion, colliding stupidly, pointlessly; and speech, talk is merely a source of fresh misunderstanding" (Kiš 165). Or, when he explains his literary craft, he says that "Truth, if only literary truth, is a type of commitment as long as a shadow of doubt hangs over every word... Writers must make us believe they know more than others yet doubt more than others" (169).

[3] Péter Esterházy (1950-2016) was one of the best known Hungarian writers and one of the leading figures of Hungarian postmodernism. His literary works were translated into more than 20 languages, and he received numerous awards for his writings. His best-known work is the novel Celestial Harmonies (Harmonia Caelestis, 2000), which was followed by Revised Edition or Corrected Version (Javított kiadás, 2002). He is the oldest son of Count Esterházy.

[4] "History is written by the victors. Traditions are woven by the people. Writers fantasize. Only death is certain."

[5] "This text contains, among other things, quotations from Danilo Kiš in literal or distorted form." 
[6] Russian word sobytie literally means "an event," so the phrase could also be translated as "an event of being."

[7] In his essays and interviews, Kiš often wrote about his (multi)linguistic "in-betweenness." For example, in an interview entitled The Only Yugoslav World Writer (Jedini jugoslavenski svetski pisac), he claims that "I can say that I truly know only one language: Serbo-Croatian, and in that language I write in Paris. I have decided not to write in another language beforehand.... Unfortunately, or thanks to God, I learned few languages, so when I sit to write, I often find the Hungarian or French word (for what I should say in Serbian) easier. For example, the word kökènyszemü: this word has meaning only in Hungarian, and it would be hopeless to try to translate it in Serbian.... Hungarian expressions are, for example, a sort of little surprises for the reader, whether they read my books in English or French translation. I want to bring them joy similar to the one I felt when I would find Hungarian words in the texts of writers from Yugoslavia in Krleža, for example" (Kiš 261).

[8] "And, in a strange inversion of time, he could already hear the guard telling the others in the officers' club, Gentlemen, the young, and here my father's name followed, slept quite soundly that night, without so much as a sigh, as if going to his wedding rather than to his hanging. I give you my word as an officer! Gentlemen, let us render him his due! After which was heard - he heard the crystal ping of glasses. Prosit! Prosit!" (Esterházy, Celestial Harmonies 24-25).

[9] "And, in a strange inversion of time, he could already hear the guard telling the officers' mess, 'Gentlemen, the young Esterházy slept quite soundly that night, without so much as a sigh, as if going to his wedding rather than to its hanging. I give you my word as an officer! Gentlemen, let us render his due!' After which is heard - he hears - the crystal pings of glasses. 'Chin chin!'” (Kiš, Encyclopedia 103-04). Comparison of English translation of Esterházy's novel (see previous footnote) and Kiš's Encyclopedia shows that the English translator of Harmonia Cælestis (unlike the translator in Croatian) used Michael Henry Heim's translation of Kiš's story, for which he - as stated in Acknowledgements - received permission from Farrar, Straus \& Giroux, LLC (Esterházy, Celestial Harmonies 847). 
[10] Legacy of Hungarian (or, more precise, Austro-Hungarian) cultural field, and Hungarian language in general, is one of the most decisive parts of Kiš's biography (see Kiš's collection of interviews Gorki talog iskustva - Bitter Residue of Experience, 1991, and Homo poeticus, his collection of essays, 1990). As a son of Hungarian-speaking Jewish railway inspector, Kiš finished Hungarian school, and later translated different Hungarian authors (Ady, József, Petöfi, Radnóti, Tolnai). His interest in Hungarian culture could also be interpreted through the lens of the fact that Danilo Kiš, the writer "who boldly embraced the ecumenical designation of the 'last Yugoslav writer"' (Debeljak 21), witnessed violence in relation to his Jewish father throughout his childhood. One massacre, in Vojvodina in 1942, he described as the start of his conscious life (cf. Thompson 82). His father's death in Auschwitz in 1944, accompanied with their troubling relationship during his childhood, had a huge impact at his life and writings: as a "mythological, rather than psychoanalytical" figure (Matvejević, cf. in Birnbaum 354), an absent father haunts Kiš’s storytelling (see also Jukić, "Between Auschwitz and Siberia"), and reverberates with his proclamation of being "the child of the Argentinian writer Jorge Luis Borges and the Polish writer Bruno Schulz" (Debeljak 21). The notion of Kiš's own preoccupation with his at once absent and omnipresent father could be interestingly interpreted through the lens of Esterházy's complex father figure in both versions of Harmonia Cælestis $(2001,2005)$.

[11] The father figure in Celestial Harmonies is not reductive, but expansive ("my father was all fathers and all men whose lives collided with Hungarian history," cf. in Sollosy ix).

[12] "Stereotext is essentially an anti-translation, as it's purpose is not in equating one language with another, but, on the contrary, in their greatest differentiation, in sharpening precisely the diverse potential of languages" (Epstein, Ot znanija 319).

[13] See one of Kiš's accounts on this issue in footnote 7.

[14] Instead of the Russian phrase svod jazykov, in his later interpretations of notion of stereotextuality Mikhail Epstein uses oxymoronic word sorazvod, which "implies integration of separated, a double act of co- and div-" (Ot znanija 320).

[15] I refer here to The Yugoslav Wars from 1991 to 1999, which led to the breakup of the 
Yugoslav state. It started after Slovenia and Croatia declared their sovereignty in 1991. The most intense fightings in the war occurred in Croatia and Bosnia and Herzegovina.

\section{(c) (i) ()}

Creative Commons Attribution-NonCommercial-NoDerivatives 4.0 International License 